\title{
Computer aided cooling curve analysis for Al-5Si and Al-11Si alloys
}

\author{
S. M. Jigajinni ${ }^{1}$, K. Venkateswarlu ${ }^{2 *}$ and S. A. Kori ${ }^{1 \#}$ \\ ${ }^{1}$ Department of Mechanical Engineering, Basaveshwar Engineering College, Bagalkot-587102, INDIA \\ ${ }^{2}$ CSIR-National Aerospace Laboratories, Bangalore-560017, INDIA \\ " Presently, Visvesvaraya Technological University, Belgaum-590018, INDIA \\ *Corresponding author: Tel +91-80-25086244; e-mail karodi2002@yhaoo.co.in (K. Venkateswarlu)
}

\begin{abstract}
The effect of grain refiner, modifier, and combination of grain refiner cum modifier was studied on Al-5Si and Al-11Si alloys using computer aided cooling curve analysis. For combined grain refinement and modification effect, Al-Ti-B-Sr single master alloy was developed that acted as both grain refiner and modifier. For thermal analysis, the temperature throughout the solidification range was recorded. The resultant plot of temperature versus time was thermal analysis. The computer aided cooling curve analysis studies shows that the extent of undercooling $\Delta \mathrm{T}_{\alpha-\mathrm{Al}}$ was reduced significantly after the addition of grain refiner to the melt. It also indicates that the eutectic temperature was suppressed on the addition of modifier to the melt.
\end{abstract}

Keywords: Aluminium-silicon; Modification; Grain refinement; Thermal analysis

DOI: http://dx.doi.org/10.4314/ijest.v3i6.21

\section{Introduction}

Aluminium-Silicon (Al-Si) alloys are considered as the most important cast alloys due to their excellent casting characteristics, good corrosion resistance, and good weldability. The fluidity of the Al-Si alloy increases up to eutectic composition (12.5\% $\mathrm{Si})$, further, presence of Si reduces hot cracking tendencies and solidification shrinkage. The overall weight of the cast component is reduced since $\mathrm{Si}$ has a low density of $2.34 \mathrm{~g} / \mathrm{cc}$. Moreover, the solubility of $\mathrm{Si}$ in $\mathrm{Al}$ is very low and precipitates as pure $\mathrm{Si}$. As a result, they are responsible for improved abrasion wear resistance (Gruzleski and Closset, 1990; Kori, 2000; Murty et al., 2003). The present work focuses on Al-5Si and Al-11Si alloys. In hypoeutectic Al-Si alloys, the major constituent is columnar $\alpha$-Al, with minor amount of randomly dispersed elongated plates or lamellae of silicon. However, in eutectic Al-Si alloys, the minor constituents consist of regular needle like eutectic Si and primary Si (infrequently formed) in addition to major $\alpha$-Al matrix (Gruzleski and Closset, 1990; Murty et al., 2003; Dahle et al., 2001, 2005; Lu and Dahle, 2006; Liao et al., 2007).

The needle type Si in, both the, hypoeutectic and the eutectic Al-Si alloys provides an effortless way for the commencement and propagation of path. This drastically lowers the tensile strength, elongation, and tribological values of the alloy. To overcome this, modifiers in the form of Sb, Na, P and Sr are added (Ho and Cantor, 1995; Dahle et al., 2005; Hegde and Prabu, 2008; Uzun et al., 2011). Among these modifiers, Sr has the rewards of long lasting (up to $2 \mathrm{~h}$ of holding) and low oxidation solubility (Kori, 2000). Hence, in the present work, the modifier in the form of Al-10Sr master alloy was used. The modifier transforms coral like Si particles into finer Si with better globular in shapes. As the percentage of Si increases, percentage of modifier also increases, as more $\mathrm{Sr}$ is needed to convert the eutectic Si (in case of Al-5Si alloy) and eutectic and primary Si (in case of Al-11Si alloy) into fine fibrous form (Hess and Blackmun, 1975; Dahle et al., 2005).

The size and shape of $\alpha-\mathrm{Al}$ in Al-Si alloy directly contributes to the mechanical properties, and it is well-known that finer $\alpha-\mathrm{Al}$ will lead to improved mechanical properties as compared to larger grains (Murty and Lakshmi, 2003). The purpose of grain refining is to: (i) improve machinability, hot 47 tearing resistance and mechanical properties; (ii) redistribute the secondary phase silicon (Si) particles; and (iii) reduce harmful effects of gas porosity and redistribution of shrinkage porosity (Gruzleski and Closset, 1990; Sigworth and Kuhn, 2007). The finer equiaxed $\alpha$-Al grains in the Al-Si alloy were obtained by adding varying ratios of Ti and B contained master alloys (McCartney, 1989;. Mayes et al., 1991; Mohanty and Gruzleski, 1996; Murty et al., 1999; 
Sigworth and Kuhn, 2007). Moreover, the effect of addition of grain refiners to various shape memory alloys was studied in detail by Albuquerque et al. (2010a,b). To refine $\alpha$-Al and to modify eutectic Si simultaneously in Al-Si melt, grain refiner and modifier are added together (Lu and Dahle, 2006; Liao et al., 2007). This leads to further improvement in the mechanical properties of Al-Si alloys (Kori et al., 2000; Basavakumar et al., 2008). Thermal analysis was used to assess the extent of grain refinement and modification on Al-Si alloy. This technique helps in controlling the size of the primary phase and the degree of modification of eutectic Si. The undercooling required for the nucleation of solid in a liquid drastically reduces in presence of heterogeneous nucleating sites present in the master alloy. When the solid completely wets the heterogeneous nucleating sites, the liquid solidifies without any undercooling as the activation barrier required for nucleation disappears. The extent of decrease in the undercooling in presence of grain refiner by heterogeneous nucleating sites is a direct measure of its grain refining efficiency. Shabestari and Malekan (2010) studied the effect of grain refinement on the solidification characteristics of A319 Al alloy using thermal analysis by the addition of Al-5Ti-1B grain refiner. An Addition of grain refiner shows grain refining effect on eutectic $\mathrm{Si}$, and interestingly, it changes nucleation growth temperatures of eutectic Si and Si particle morphology. Chen et al. (2006) investigated eutectic modification of Al-7Si alloy by computer aided thermal analysis cooling curves. The eutectic temperature depression can be used as a characteristic parameter to qualitatively evaluate the modification effect of Al-7Si alloys, but it cannot serve as a parameter to quantitatively predict the modification level of Al-7Si alloys, especially when the modification level is in the highlevel range from 4 to 6. Hegde and Prabhu (2008) studied the modification effect of eutectic silicon in Al-Si alloys using thermal analysis tool, which can be effectively assessed by the parameters like eutectic depression, undercooling magnitude and time. Further, they also claimed that a single cooling curve parameter is not sufficient to make accurate prediction of modified structure as many variables affect the thermal analysis results. For example, a change in $\mathrm{Mg}$ concentration in the melt alters the cooling curve parameter. Nafisi and Ghomashchi (2007) shows that addition of $200 \mathrm{ppm}$ of boron to A356 alloy eliminates the undercooling and there is no recalescence so that there is no falling of temperature continuously after nucleation. Therefore, the grain refiner is considered as ideal when there is no recalescence. In other words, the smaller recalescence leads to more effective refining. When an Al-Si melt is modified, the eutectic temperature is depressed and the extent of depression of the eutectic temperature can be a measure of the degree of modification (Apelian et al., 1984). In LM-6 alloy, modification of $0.50 \mathrm{wt} \%$ of Al$10 \mathrm{Sr}$ modifier transforms the solidification in to a complete eutectic solidification at $540^{\circ} \mathrm{C}$. This eutectic temperature is lower than the solidus temperature $\left(565^{\circ} \mathrm{C}\right.$ ) of LM-6. This implies that by adding the modifier to LM-6 alloy, the superheat of the melt in the furnace can be reduced to save electrical energy consumption, while ensuring complete liquid mold filling (Lim, 2009). Because of modification, the eutectic composition also shifts towards the higher Si content.

Thus, the thermal analysis can be a potential tool for the assessment of not only the grain refinement but also the degree of modification achieved by the modifier in both hypoeutectic and eutectic Al-Si alloys. One cooling curve experiment has the potential to evaluate both the above phenomena simultaneously. Hence, assessment of both grain refining and modifying efficiency of the newly developed grain refiner cum modifier master alloy using Al-Si alloys with the help of thermal analysis before casting is of great industrial importance. Further, the magnitude of the undercooling helps in assessing the microstructures of the alloys. Albuquerque et al. extensively studied a new computational solution to quantify synthetic material porosity from optical microscopic images and same technique is used on composites. Albuquerque et al. (2008, 2010c, 2011). Hence, thermal Analysis acts as a real time statistical quality control tool in aluminum casting.

During modification of Al-Si melt, the eutectic temperature is suppressed and the extent of suppression of the eutectic temperature can be a measure of the degree of modification (Apelian et al., 1984). Thus, the computer aided cooling curve analysis (CA-CCA) can be used to assess, both, the grain refining efficiency of the grain refiner and the degree of modification achieved by the modifier in hypoeutectic and eutectic Al-Si alloys. As a result, a single cooling curve experiment can be used to evaluate both the effects of grain refinement and modification simultaneously.

In the present work, an attempt was made to develop a single master alloy such that it contains the constituents of both grain refiner and modifier, which helps in converting, simultaneously, coarse columnar $\alpha$-Al into equiaxed $\alpha-\mathrm{Al}$ grains and eutectic needle type Si particles into fibrous Si particles simultaneously. Further, the addition of newly developed grain refiner cum modifier to Al-Si melt can lead to several advantages: i) quick combined grain refinement and modification effect in single stage; ii) simplified foundry operations due to cumulation of two operations into one leading to reduction in manufacturing cost; and iii) best quality of the cast parts due to the absence of micro shrinkage and hot cracking tendency. Grain refinement is achieved in Al5Si and Al-11Si alloys with the help of Al-1Ti-3B master alloy that has been assessed using CA-CCA. Further, the same technique can be used on Al-5Si and Al-11Si alloys to assess the effect of modification using Al-10Sr master alloy and combined grain refinement cum modification using Al-Ti-B-Sr master alloys. The required starting materials for grain refinement of Al-Si alloys using master alloys is explained in experimental chapter and results obtained by using combination of grain refiner cum modifier is also explained and discussed in detail in results and discussion. The observations from the present investigation are clearly mentioned in conclusions.

\section{Experimental Details}

In the present study, Al-1Ti-3B master alloy as grain refiner (MA1) was prepared by the reaction of $\mathrm{Al}$ melt with halide salts $\left(\mathrm{K}_{2} \mathrm{TiF}_{6}\right.$ and $\left.\mathrm{KBF}_{4}\right)$ at a reaction temperature of $800^{\circ} \mathrm{C}$ and a reaction time of $60 \mathrm{~min}$. in an induction furnace. The indigenously 
developed MA1 master alloy was used for the grain refinement studies of Al-5Si and Al-11Si alloys using CA-CCA studies. The alloys $\mathrm{Al}-5 \mathrm{Si}$ and $\mathrm{Al}-11 \mathrm{Si}$ were prepared in an electric resistance furnace using commercial pure $\mathrm{Al}$ and $\mathrm{Al}-20 \mathrm{wt} \% \mathrm{Si}$ master alloy under a cover flux $(45 \mathrm{wt} \% \mathrm{NaCl}+45 \mathrm{wt} \% \mathrm{KCl}+10 \mathrm{wt} \% \mathrm{NaF})$ and the melt was held at $720^{\circ} \mathrm{C}$. The melt was treated with $1 \mathrm{wt} \%$ solid hexachloroethane $\left(\mathrm{C}_{2} \mathrm{Cl}_{6}\right)$ degasser, followed by MA1 additions to the melt for grain refinement purpose. After the addition of MA1, the melt was stirred gently with zircon coated iron rod and was held for $5 \mathrm{~min}$. before it was poured into a preheated $\left(150^{\circ} \mathrm{C}\right)$ cylindrical sand mould. A chromel-alumel thermocouple was used to measure the temperature variation during solidification.

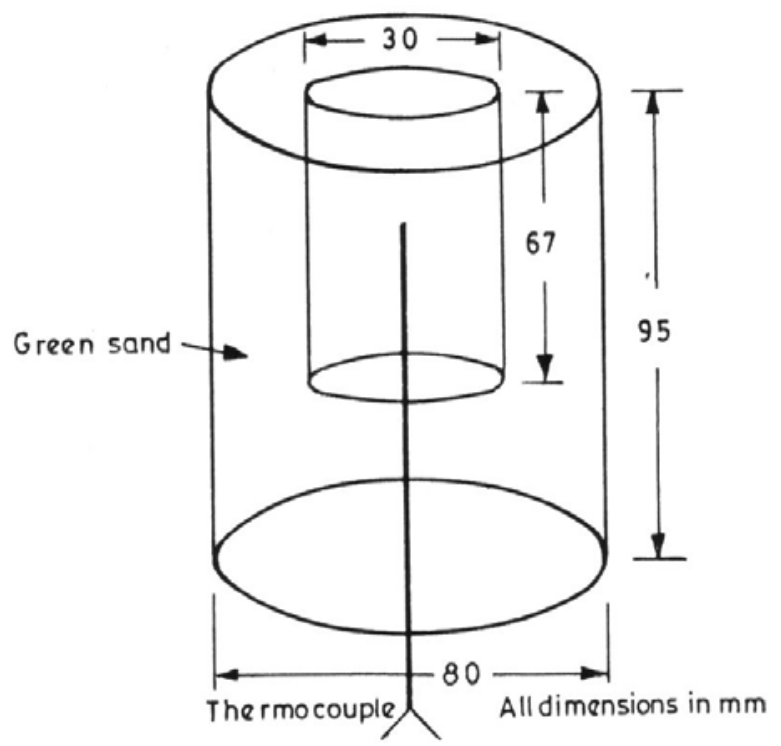

Figure 1 Dimensions of the cylindrical mould and thermocouple positions used for thermal analysis studies (CACCA)

Figure 1 shows the dimensions of the cylindrical mould and thermocouple positions used for thermal analysis studies (CACCA). The cooling curves during solidification were recorded using computer data acquisition system (DATA LOGGER, Ceratherm International, Bangalore) having temperature and time sensitivities of $0.1^{\circ} \mathrm{C}$ and $0.15 \mathrm{~s}$ respectively. The extent of degree of undercooling obtained was determined using PRODAS-2003 software.

A similar procedure was adopted for the modification and combined grain refinement cum modification of Al-5Si and Al-11Si alloys. Al-10Sr master alloy (MA2) in required quantities was added to Al-5Si and Al-11Si alloys for the modification purpose. For combined grain refinement and modification studies, the MA1 alloy was added to MA2 alloy in an electrical resistance furnace to form a new combination of quaternary Al-1Ti-3B-2Sr (MA3) and Al-1Ti-3B-4.6Sr (MA4) master alloys. MA3 was added to Al5Si melt and MA4 was added to Al-11Si melt. The influence of these newly developed grain refiner cum modifiers were then used for simultaneous grain refinement and modification studies using CA-CCA. The composition of the newly developed master alloy for the preparation was chosen based on the optimum addition levels of both grain refiner and modifier.

Table 1 Optimum addition levels of various master alloys to Al-5Si and Al-11Si alloys.

\begin{tabular}{llcccc}
\hline Alloy & Master alloy/Code & $\begin{array}{c}\text { Optimum addition } \\
\text { level of master alloy } \\
\text { (wt \%) }\end{array}$ & Ti\% & B\% & Sr\% \\
\hline Al-5Si & Al-1Ti-3B/MA1 & 0.50 & 0.0050 & 0.0150 & - \\
Al-5Si & Al-10Sr/MA2 & 0.10 & - & - & 0.0100 \\
Al-5Si & Al-1Ti-3B-2Sr/MA3 & 0.50 & 0.0050 & 0.0150 & 0.0100 \\
Al-11Si & Al-1Ti-3B/MA1 & 0.65 & 0.0065 & 0.0195 & - \\
Al-11Si & Al-10Sr/MA2 & 0.30 & - & - & 0.0300 \\
Al-11Si & Al-1Ti-3B-4.6Sr/MA4 & 0.65 & 0.0065 & 0.0195 & 0.0300 \\
\hline
\end{tabular}

Table 1 shows optimum addition levels of various master alloys to Al-5Si and Al-11Si alloys. 


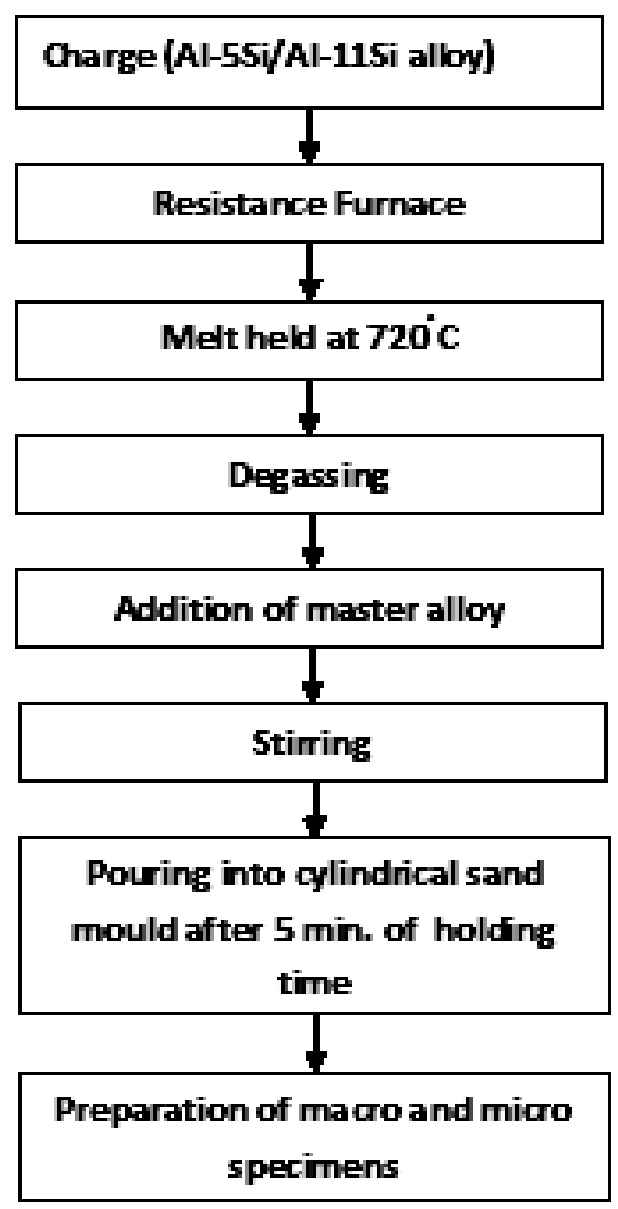

Figure 2. Flow chart for the processing of grain refinement, modification and combined additions

Figure 2 shows the flow chart for the processing of grain refinement, modification and combined additions. The grain refined, modified and combined grain refined and modified samples were metallographically polished and etched with Keller's reagent $\left(2.5 \% \mathrm{HNO}_{3}+1.5 \%+\mathrm{HCl}, 1 \% \mathrm{HF}+95 \% \mathrm{H}_{2} \mathrm{O}\right.$ by volume) and examined under SEM (JSM 840A, Jeol make, Japan) for microstructural studies and dendtrite arm spacing (DAS) measurements using an image analyzer.

\section{Results and Discussion}

The chemical compositions of various master alloys and as-cast alloys were assessed using atomic absorption spectrometer (model AA-670, Varian, The Netherlands) as listed in Table 2.

Table 2 Chemical compositions of various master alloys and cast alloys used in the present study.

\begin{tabular}{ccccccc}
\hline Alloy Composition & \multicolumn{7}{c}{ Composition (wt\%) } \\
\cline { 2 - 7 } & $\mathrm{Ti}$ & $\mathrm{B}$ & $\mathrm{Sr}$ & $\mathrm{Si}$ & $\mathrm{Fe}$ & $\mathrm{Al}$ \\
\hline MA1 & 1.00 & 2.41 & - & 0.15 & 0.15 & Balance \\
MA2 & - & - & 9.93 & 0.16 & 0.14 & Balance \\
MA3 & 1.0 & 2.29 & 1.9 & 0.14 & 0.15 & Balance \\
MA4 & 1.1 & 2.30 & 4.4 & 0.15 & 0.15 & Balance \\
Al-5Si & - & - & - & 4.93 & 0.15 & Balance \\
Al-11Si & - & - & - & 10.95 & 0.16 & Balance \\
\hline
\end{tabular}




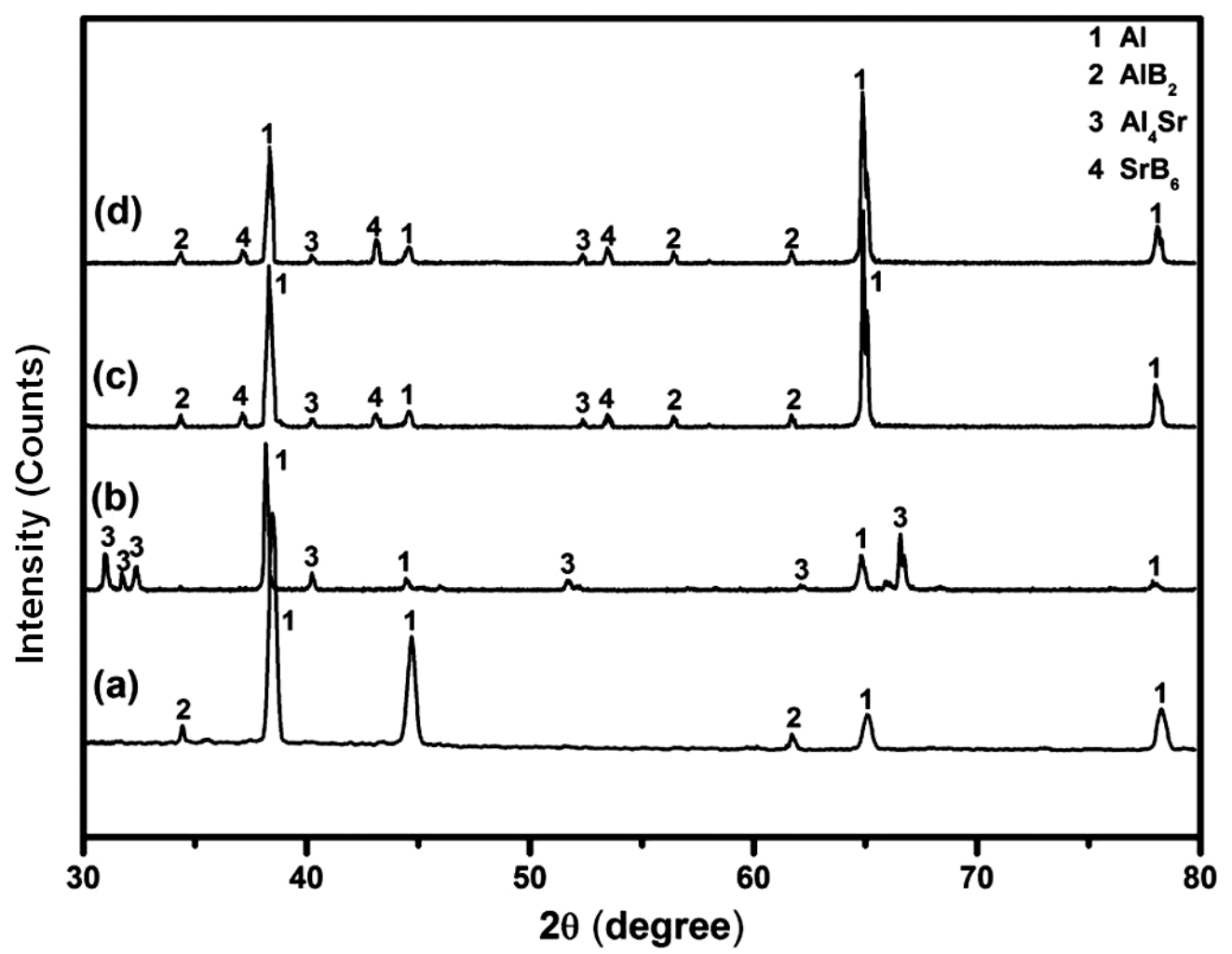

Figure 3 XRD patterns of (a) MA1, (b) MA2, (c) MA3, and (d) MA4 alloys.

Figure 3a shows the XRD patterns of MAl and contirms the presence of $\mathrm{AlB}_{2}$ and Al. Due to similar crystal structures and lattice parameters of $\mathrm{TiB}_{2}$ and $\mathrm{AlB}_{2}$, the XRD peaks overlap and the presence of $\mathrm{TiB}_{2}$ does not reflect in the XRD patterns (Marcantonio and Mondolfo, 1971; Cornish, 1975; Kiusalaas, 1986; Fjellstedt et al., 1999; Lu and Dahle, 2006). The XRD peaks of MA2 master alloy indicate the presence of $\alpha-\mathrm{Al}$ and $\mathrm{Al}_{4} \mathrm{Sr}$ phases as shown in Fig. 3b. Figures 3c and, d shows the X-ray diffraction peaks of MA3 and MA4, respectively confirming the presence of $\alpha-\mathrm{Al}, \mathrm{AlB}_{2}$ and $\mathrm{SrB}_{6}$ phases in MA3 and MA4 alloys. B-rich content in MA1 consists of mixed borides $(\mathrm{Al}, \mathrm{Ti}) \mathrm{B}_{2}$, from which it is believed that only $\mathrm{AlB}_{2}$ particles of MA1alloy reacts with Sr particles of MA2 to form strontium boride with a theoretical density of $3.42 \mathrm{~g} / \mathrm{cc}$. The reaction can be expressed as follows ((Lu and Dahle, 2006):

$$
\left[S r+3 A l B_{2}(S)\right] \rightarrow \operatorname{SrB}_{6}(S)+3[A l]
$$

Figure 4a shows the SEM photograph of MA1. From Fig. 4a, it is clear that the particles have not only grown in size $(2-15 \mu \mathrm{m})$ but also have acquired a hexagonal shape. These particles are $\mathrm{AlB}_{2}$ particles as confirmed by XRD studies. Figure 4b shows SEM photograph of MA2 consisting of sugarcane like $\mathrm{Al}_{4} \mathrm{Sr}$ particles in an $\alpha-\mathrm{Al}$ matrix and are confirmed by XRD results (Figure 3b). Figures 4c and, d show SEM photographs of MA3 and MA4, respectively indicating the presence of very fine (Al,Ti) $\mathrm{B}_{2}$ and $\mathrm{SrB}_{6}$ particles.

Assessment of the performance of MA1 on Al-5Si and Al-11Si alloys was carried out using CA-CCA. Cooling curves were plotted for each alloy without and with the addition of grain refiner. The liquidus temperature $\left(T_{L}\right)$, the undercooling temperature $\left(\mathrm{T}_{\mathrm{U}}\right)$ and the eutectic temperature $\left(\mathrm{T}_{\mathrm{EUT}}\right)$ were recorded with the help of an 8-channel data logger with a sensitivity of $0.1^{\circ} \mathrm{C}$ and 0.25 s intervals. 

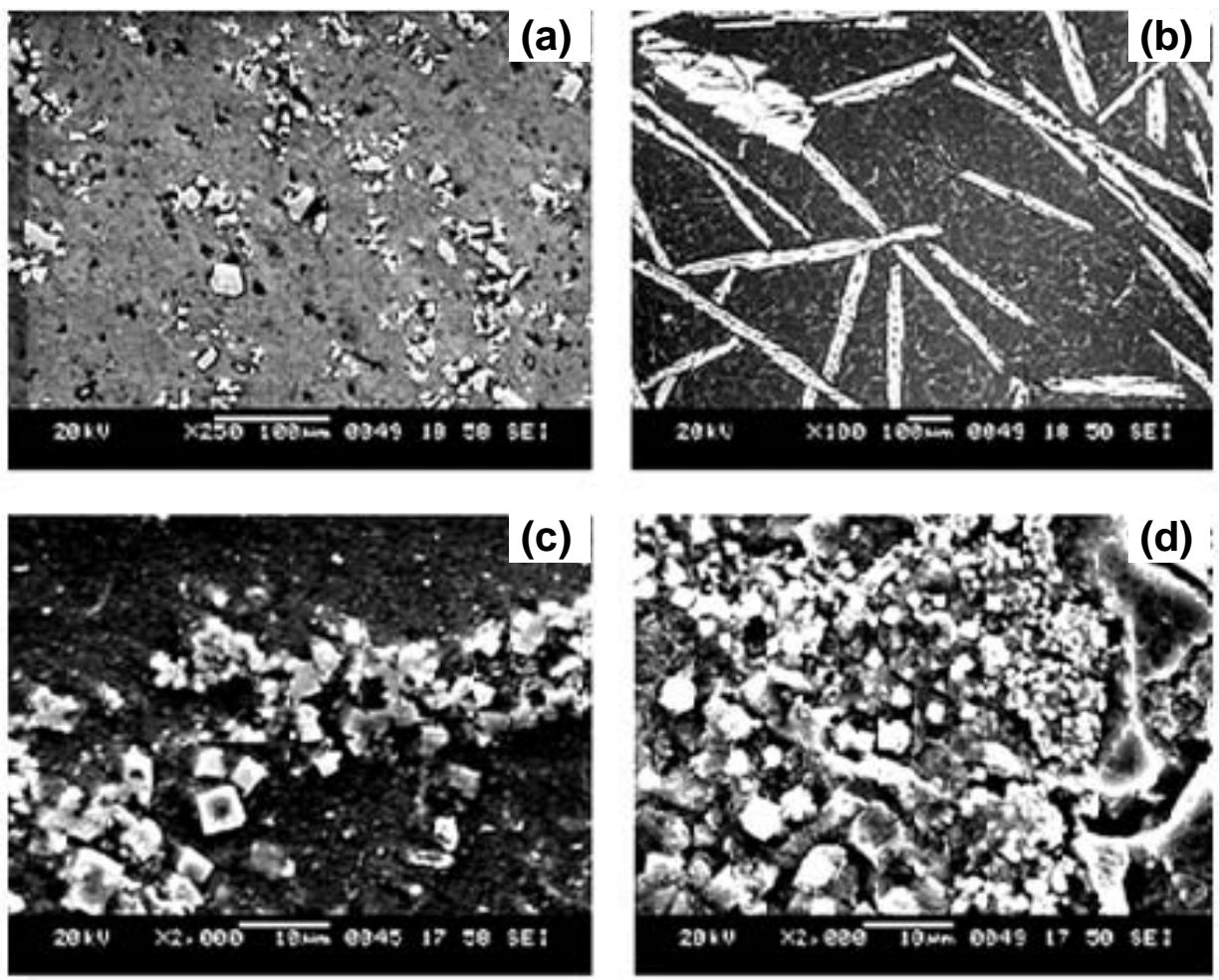

Figure 4. SEM photographs of (a) MA1, (b) MA2, (c) MA3, and (d) MA4 alloys.

Table 3 Details of cooling curve analysis of Al-5Si and Al-11Si alloys carried out using conventional and newly developed master alloys at $720^{\circ} \mathrm{C}$.

\begin{tabular}{|c|c|c|c|c|c|}
\hline Alloy Composition & $\begin{array}{l}\text { Optimum addition } \\
\text { level of master } \\
\text { alloy (wt \%) }\end{array}$ & $\begin{array}{l}\text { Addition level } \\
\text { of Modifier (\%) }\end{array}$ & $\begin{array}{l}\Delta \mathrm{T}_{\alpha}-\mathrm{Al} \\
\left(\mathrm{T}_{\mathrm{L}}-\mathrm{T}_{\mathrm{U}}\right){ }^{\circ} \mathrm{C}\end{array}$ & $\begin{array}{l}\text { Eutectic } \\
\text { Temp. }{ }^{\circ} \mathrm{C}\end{array}$ & $\begin{array}{l}\text { DAS } \\
\text { in } \mu \mathrm{m}\end{array}$ \\
\hline Al-5Si & - & - & 1.68 & 569.13 & 90 \\
\hline Al-5Si + MA1 & 0.50 & - & 0.40 & 568.50 & 32 \\
\hline Al-5Si + MA2 & 0.10 & 0.010 & 1.40 & 561.40 & 49 \\
\hline Al-5Si + MA3 & 0.50 & 0.010 & 0 & 564.10 & 32 \\
\hline Al-11Si & - & - & 2.31 & 577.96 & 99 \\
\hline Al-11Si + MA1 & 0.65 & - & 0 & 579.51 & 39 \\
\hline Al-11Si + MA2 & 0.30 & 0.030 & 1.13 & 570.30 & 54 \\
\hline Al-11Si + MA4 & 0.65 & 0.030 & 0 & 571.50 & 39 \\
\hline
\end{tabular}

Table 3 shows the details of undercooling $\left(\Delta \mathrm{T}_{\alpha-\mathrm{Al}}=\mathrm{T}_{\mathrm{L}}-\mathrm{T}_{\mathrm{U}}\right)$ for $\alpha-\mathrm{Al}$ and eutectic temperature of Al-5Si and Al-11Si alloys using different master alloys.

Figure 5a represents the cooling curve of Al-5Si alloy with an undercooling $\left(\Delta \mathrm{T}_{\alpha-\mathrm{Al}}\right)$ of $1.68^{\circ} \mathrm{C}$ at $619.2^{\circ} \mathrm{C}$ followed by eutectic temperature of $569.13^{\circ} \mathrm{C}$. Al-5Si alloy has a DAS value of $90 \mu \mathrm{m}$ in the absence of grain refiner. It is apparent that $\alpha$-Al dendrites nucleate at $619.2^{\circ} \mathrm{C}$ and the growth is followed by eutectic solidification. The nucleation of $\alpha$-Al needs an undercooling of $1.68^{\circ} \mathrm{C}$. However, with individual addition of $0.50 \mathrm{wt} \%$ of MA1 master alloy to Al-5Si alloy, undercooling decreases from $1.68^{\circ} \mathrm{C}$ to $0.40^{\circ} \mathrm{C}$, whereas the eutectic temperature also decreases from $569.13^{\circ} \mathrm{C}$ to $568.50^{\circ} \mathrm{C}$ as can be observed in Fig. $5 \mathrm{~b}$. The undercooling required for the nucleation of solid aluminium in a liquid is drastically reduced in presence of heterogeneous nucleating sites like $\mathrm{Al}_{3} \mathrm{Ti}, \mathrm{TiB}_{2}$ and $(\mathrm{Al}, \mathrm{Ti}) \mathrm{B}_{2}$ particles present in the MA1 master alloy. When the solid completely wets the 
heterogeneous nucleating sites, the liquid solidifies with small amount of undercooling $\left(0.40^{\circ} \mathrm{C}\right)$ as shown in Fig. $5 \mathrm{~b}$, as the activation barrier required for nucleation disappears. Therefore, addition of grain refiner will provide higher level of nucleants in the melt, thereby decreasing the magnitude of undercooling. The decreased magnitude of undercooling is the indication of fine grain structure in the casting (Apelian et al., 1984), which in turn are supported in the present work by a decreased DAS value of $32 \mu \mathrm{m}$.
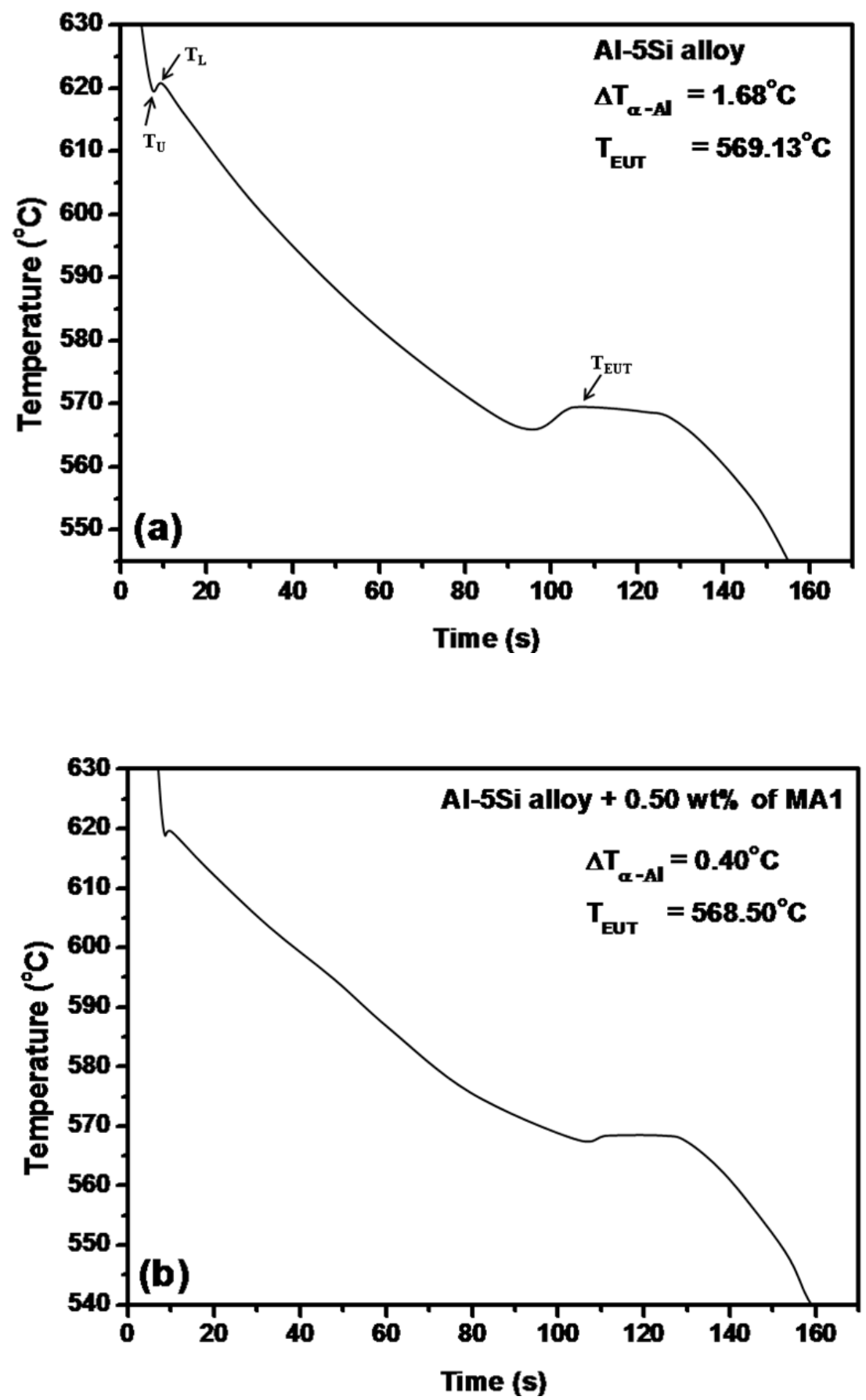

Figure 5. Thermal analysis cooling curves of Al-5Si alloy (a) without grain refiner and (b) with $0.50 \mathrm{wt} \%$ of MA1. 

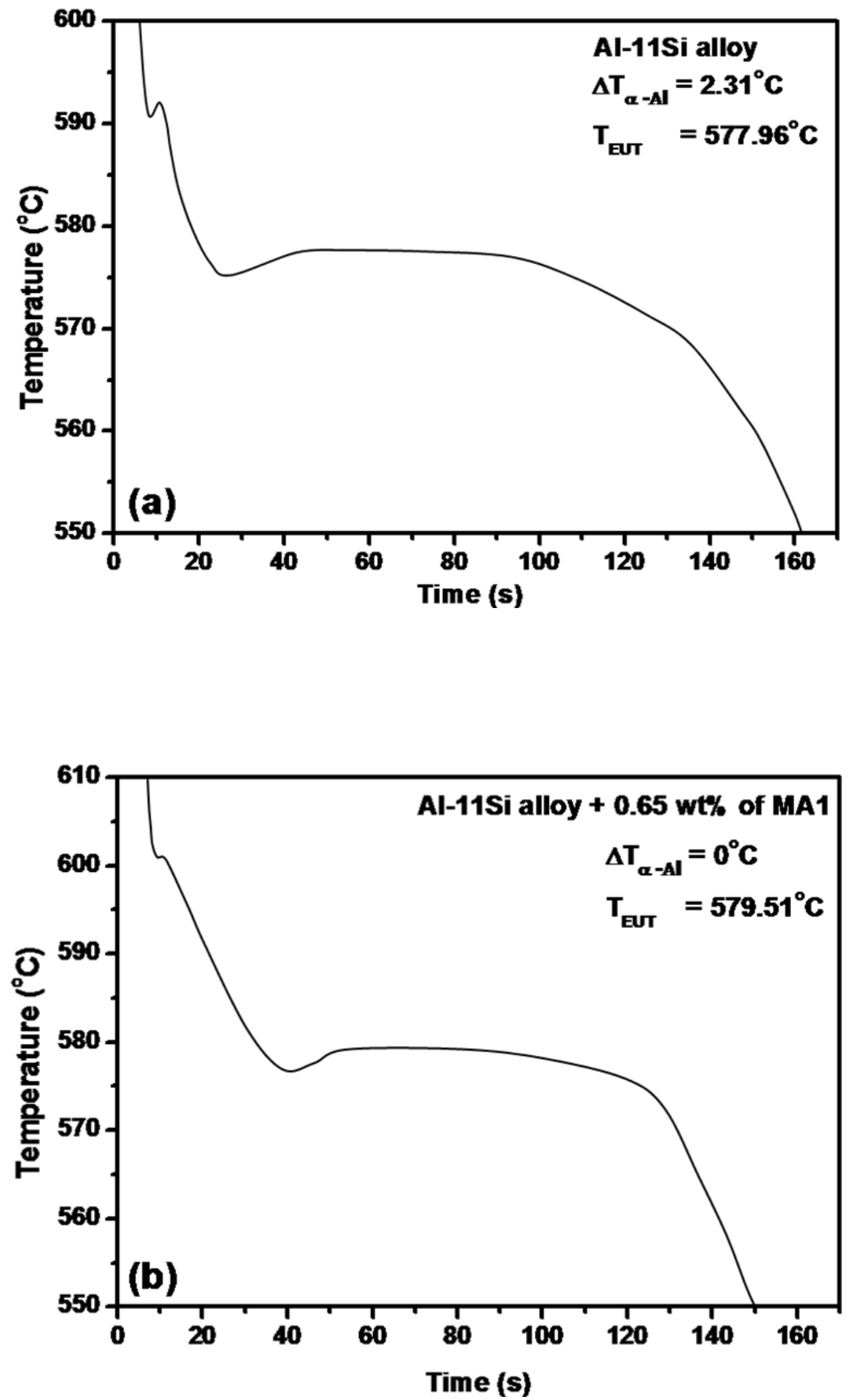

Figure 6 Thermal analysis cooling curves of Al-11Si alloy (a) without grain refiner and (b) with $0.65 \mathrm{wt} \%$ of MA1.

CA-CCA studies of Figures $6 \mathrm{a}$ and $6 \mathrm{~b}$ show the cooling curves of Al-11Si alloy without and with addition of 0.65 wt $\%$ of MA1. $\mathrm{Al}-11 \mathrm{Si}$ alloy has shown undercooling of $2.31^{\circ} \mathrm{C}$ in the absence of grain refiner and $0^{\circ} \mathrm{C}$ in presence of grain refiner. It may be noted that the solidification of Al-11Si alloy proceeds with higher amount of undercooling $\left(2.31^{\circ} \mathrm{C}\right)$ compared to Al-5Si alloy $\left(1.68^{\circ} \mathrm{C}\right)$. The higher amount of undercooling in Al-11Si alloy confirms with the earlier findings (Kori et al., 2000) that the undercooling required for the nucleation of $\alpha$-Al increases with increase in silicon content of the hypoeutectic and eutectic $\mathrm{Al}-\mathrm{Si}$ alloys. Thus, the increase in undercooling can be attributed to the increased superheat. Higher superheat invariably results in increased undercooling. It is also likely that the nucleation of $\alpha$-Al results in the release of higher amount of latent heat as the $\mathrm{Si}$ 
content in the Al-Si increases. The latent heat of freezing Al-Si alloy is known to increase with increase in Si content (Kiusalaas, 1986; Hegde and Prabhu, 2008). Thus, a release of higher amount of latent heat will result in higher degree of recalescence. The zero undercooling shown in Fig. 6b clearly shows that the addition of $0.65 \mathrm{wt} \%$ of MA1 master alloy is highly efficient in heterogeneously nucleating $\alpha$-Al of $\mathrm{Al}-11 \mathrm{Si}$ alloy due to the presence of $\mathrm{Al}_{3} \mathrm{Ti}, \mathrm{TiB}_{2}$ and (Al, Ti)B $\mathrm{B}_{2}$ particles present in the $\mathrm{MA} 1$ master alloy. In other words, addition of MA1 to Al-11Si alloy results in better grain refinement compared to addition of MA1 to Al-5Si alloy (Fig. 5b) with the undercooling of $0.4^{\circ} \mathrm{C}$. As reported by Apelian et al. (1984), it was found that the grain size is relatively fine if the value of $\mathrm{T}_{\mathrm{L}}-\mathrm{T}_{\mathrm{U}}$ is less than $0.3^{\circ} \mathrm{C}$. A decrease in DAS value of $39 \mu \mathrm{m}$ was observed with the addition of MA1 to $\mathrm{Al}-11 \mathrm{Si}$ alloy compared to the absence of grain refiner $(99 \mu \mathrm{m})$.
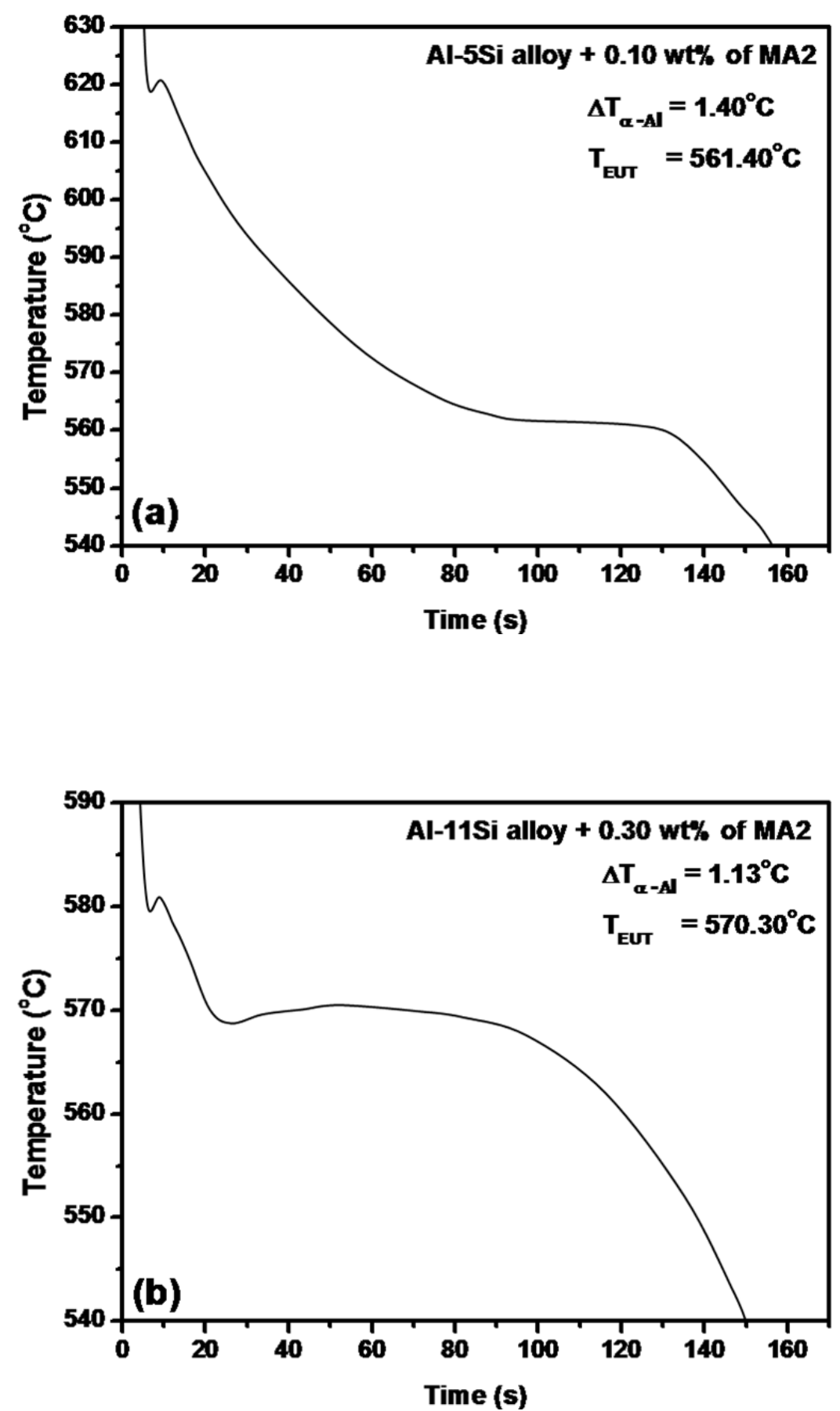

Figure 7 Thermal analysis cooling curves of (a) Al-5Si alloy with 0.10 wt $\%$ of MA2 and (b) Al-11Si alloy with $0.30 \mathrm{wt} \%$ of MA2. 
Figure 7a shows the cooling curve of Al-5Si alloy after the addition of $0.10 \mathrm{wt} \%$ of MA2. The alloy do not show any significant change in the undercooling $\left(\Delta \mathrm{T}_{\alpha-\mathrm{Al}}\right)$ in presence of modifier $\left(1.40^{\circ} \mathrm{C}\right)$ when compared to the as cast condition $\left(1.68^{\circ} \mathrm{C}\right)$. However, the eutectic temperature is significantly suppressed by $7.73^{\circ} \mathrm{C}\left(561.40^{\circ} \mathrm{C}\right)$. The depression of the eutectic growth temperature represents the temperature difference between the unmodified $\left(569.13^{\circ} \mathrm{C}\right)$ and modified $\mathrm{Al}-5 \mathrm{Si}$ alloy $\left(561.40^{\circ} \mathrm{C}\right)$ eutectic growth temperatures. The large depression of magnitude of eutectic growth temperature represents the higher level of modification leading to smaller size of silicon particles (Djurdjević et al., 2010). However, it was also observed that there is a partial refinement of $\alpha$-Al dendrites in addition to eutectic modification by the addition of MA2 master alloy.
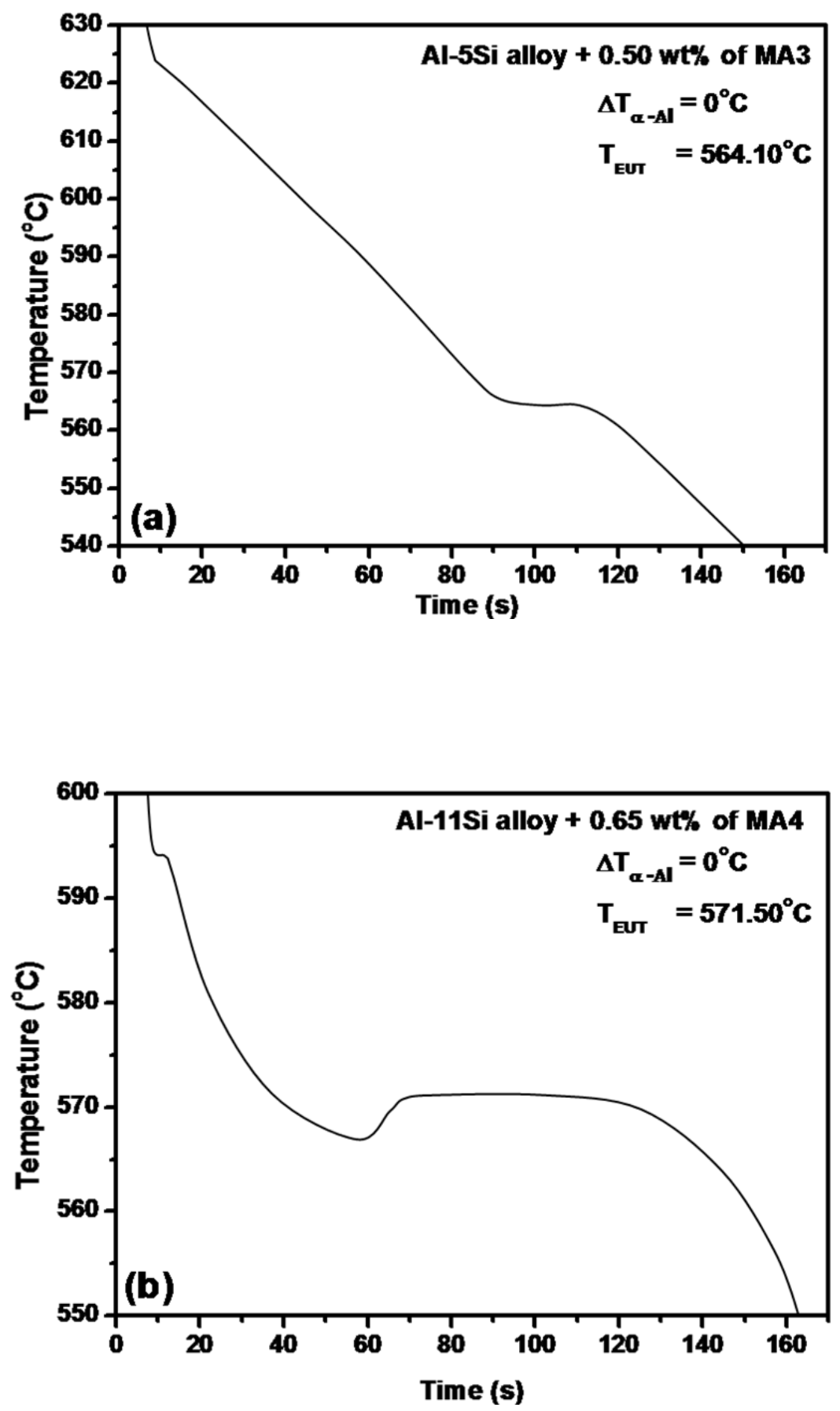

Figure 8 Thermal analysis cooling curves of (a) Al-5Si alloy with $0.50 \mathrm{wt} \%$ of MA3 and (b) Al-11Si alloy with $0.65 \mathrm{wt} \%$ of MA4. 
This could be due to the suppression of eutectic temperature resulting in a higher superheat (as the pouring temperature being $720^{\circ} \mathrm{C}$ ) and hence higher undercooling. The undercooling of the melt causes an increase in the nucleation rate and hence partial refinement of the $\alpha$-Al dendrites. This leads to smaller DAS value for Al-5Si alloy that was modified with MA2 (49 $\mu$ m, after 5 min. of holding time as mentioned in Table 3). Thus, it is clear that the thermal analysis results are very sensitive to the modification effect in case of Al-5Si alloy. An addition of $0.30 \mathrm{wt} \%$ of MA2 to Al-11Si alloy results in a cooling curve as shown in Fig. $7 \mathrm{~b}$. The alloy shows marginal decrease in the undercooling $\left(\Delta \mathrm{T}_{\alpha-\mathrm{Al}}\right)$ in presence of modifier $\left(1.13^{\circ} \mathrm{C}\right)$ against $2.31^{\circ} \mathrm{C}$, observed in the untreated condition. The eutectic temperature is decreased significantly by $7.66^{\circ} \mathrm{C}\left(570.30^{\circ} \mathrm{C}\right)$. Further, a decrease in DAS value of $54 \mu \mathrm{m}$ was observed with the addition of MA2 modifier to Al-11Si alloy as compared to without modifier (99 $\mu \mathrm{m})$.

Figure 8a shows thermal analysis curve for Al-5Si alloy with the addition of $0.50 \mathrm{wt} \%$ of MA3. It is clear that $\Delta \mathrm{T}_{\alpha-\mathrm{Al}}$ approaches $0^{\circ} \mathrm{C}$, in addition to decrease in eutectic temperature from $569.13^{\circ} \mathrm{C}$ to $564.10^{\circ} \mathrm{C}$. Therefore, it is clear from the cooling curve of Fig. 8a that, zero undercooling is representing grain refinement of $\alpha-\mathrm{Al}$ and significant depression of eutectic temperature is the measure of modification of eutectic Si in Al-5Si alloy. Similarly, addition of $0.65 \mathrm{wt} \%$ of MA4 to Al-11Si alloy significantly decreases the values of undercooling to $0^{\circ} \mathrm{C}$ and eutectic temperature by $6.46^{\circ} \mathrm{C}$ (from $577.50^{\circ} \mathrm{C}$ to $565.86^{\circ} \mathrm{C}$ ) respectively as shown in Fig. 8b. In other words, a combined effect of grain refinement and modification was achieved when MA4 master alloy was added to Al-11Si alloy.

It is thus evident that the presence of grain refiner (MA1) has no influence on the modification effect of the eutectic Si but presence of modifier (MA2) is responsible for the partial grain refinement of $\alpha$-Al dendrites in Al-5Si and Al-11Si alloys. The former is supported by decrease in DAS values of $49 \mu \mathrm{m}$ and $54 \mu \mathrm{m}$ respectively as indicted in Table 3.

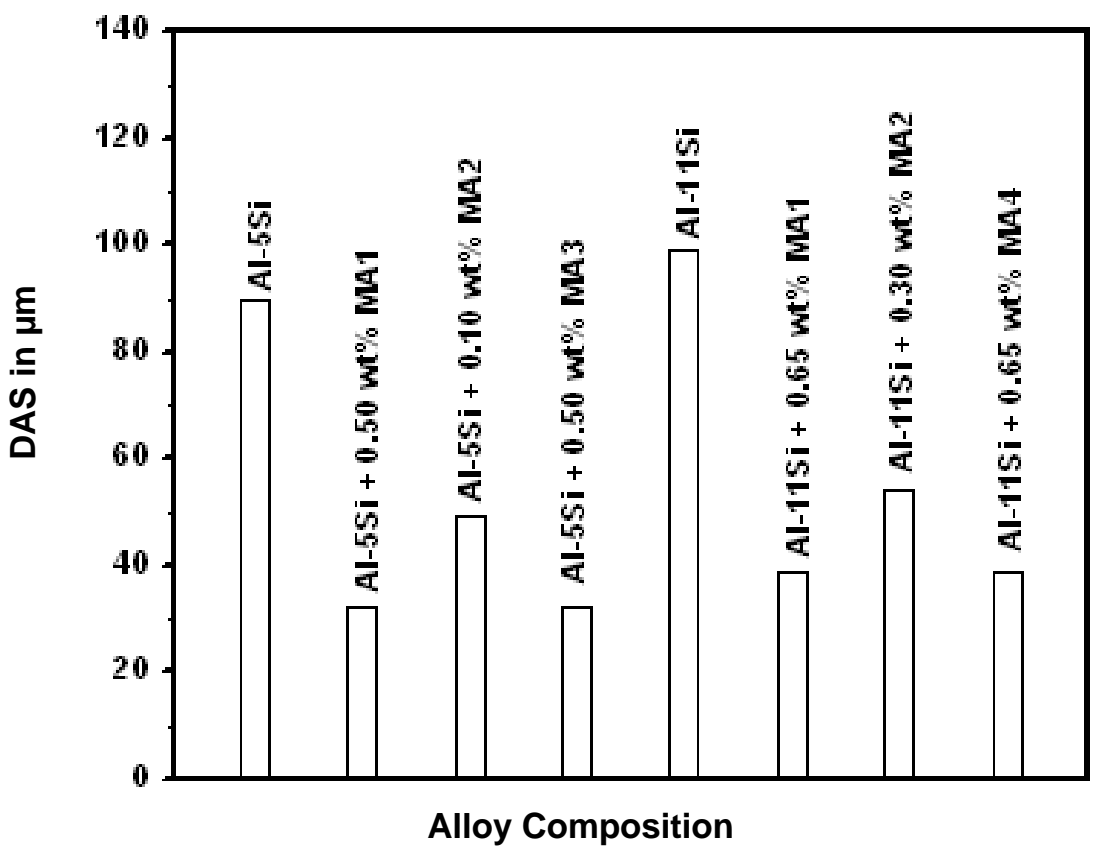

Figure 9 shows the comparison of DAS values of Al-5Si and Al-11Si alloys before and after the addition of grain refiner, modifier, and their combined additions. Thus, the CA-CCA analysis can assess the effectiveness of grain refiner, modifier, and combined addition of grain refiner and modifier. 

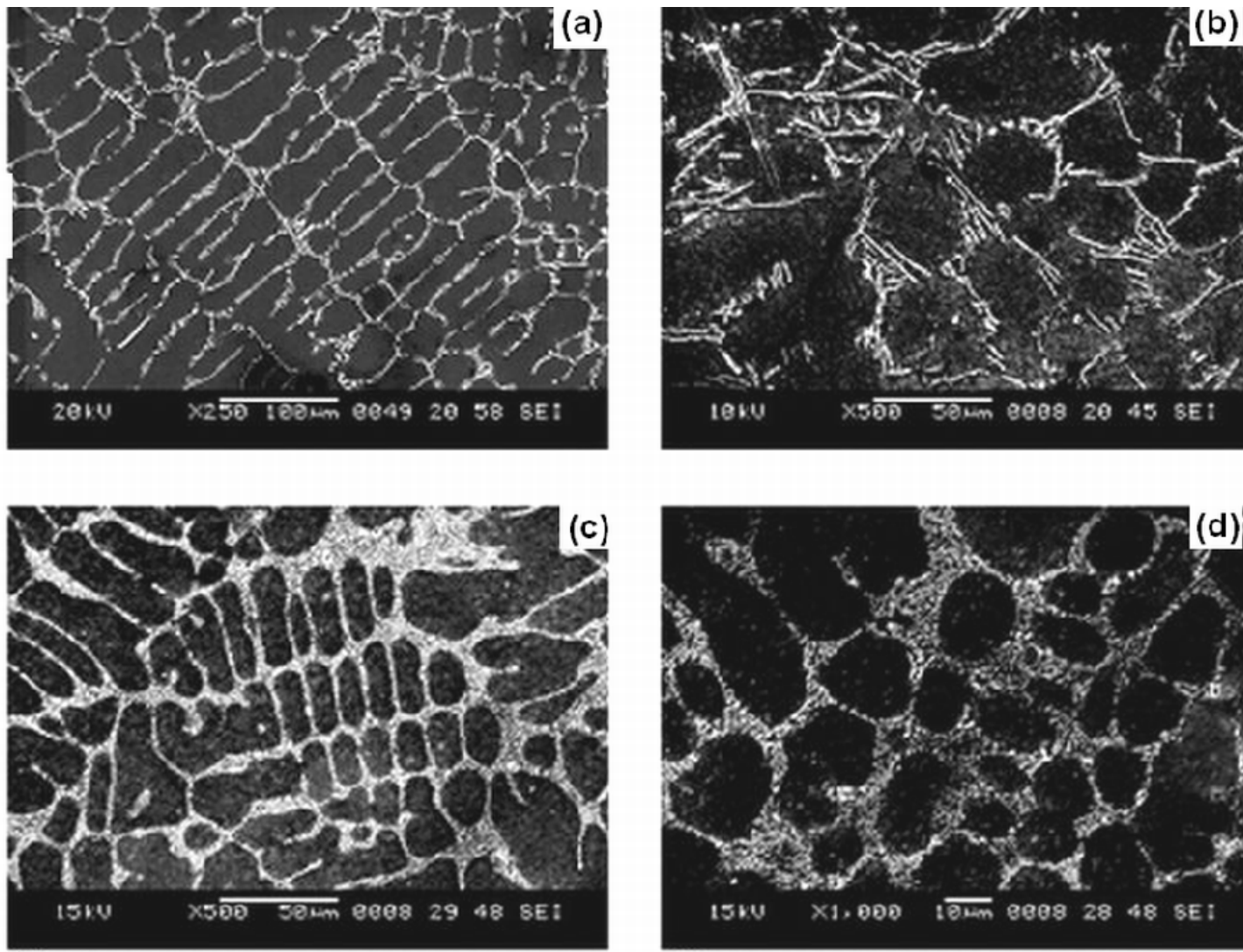

Figure 10. SEM photographs of Al-5Si alloy (a) without master alloy, (b) with 0.50 wt\% of MA1, (c) with 0.10 wt $\%$ of MA2, and (d) with $0.50 \mathrm{wt} \%$ of MA3.

Figure 10a shows SEM photograph of Al-5Si alloy in the absence of grain refiner (0 min.). It is clear from Fig. 10a that, the alloy solidifies with columnar dendritic structure in the absence of grain refiner with large eutectic Si needles/flakes at the grain boundaries of columnar $\alpha$-Al dendrites. Good grain refinement of $\alpha$-Al dendrites was observed as in Fig. 10b, when $0.50 \mathrm{wt} \%$ of MA1 was added to Al-5Si alloy. The addition of $0.50 \mathrm{wt} \%$ of MA1 significantly refines the $\alpha$-Al dendrites and converts them from columnar to fine equiaxed dendrites. Figure 10b shows no evidence of columnar dendritic pattern and formation of an equiaxed structure in the Al-5Si alloy. Such conversion is due to the heterogeneous nucleating action of mixed boride (Al,Ti) $\mathrm{B}_{2}$ along with $\mathrm{TiB}_{2}$ and $\mathrm{Al}_{3} \mathrm{Ti}$ particles present in MA1 master alloy. However, eutectic Si remains as unmodified eutectic needle form, as is evident from Fig. 10b. In other words, addition of grain refiner is not affecting the eutectic Si.

Figure 10c shows the SEM photograph of Al-5Si alloy with $0.10 \mathrm{wt} \%$ addition level of MA2 master alloy. It is clear that in the absence of modifier (Fig. 10a), the structure of the Al-5Si alloy consists of unmodified eutectic silicon in the form of needles together with elongated columnar $\alpha$-Al dendrites. However, individual additions of $0.10 \mathrm{wt} \%$ of MA2 to Al-5Si alloy convert the flake particles of silicon into fine particles of silicon, which are confirmed as in Fig. 10c. Figure 10c also shows that, when MA2 is added to $\mathrm{Al}-5 \mathrm{Si}$ alloy, there is a partial refinement of $\alpha$-Al dendrites in addition to eutectic modification. The reason for partial refinement was similar as mentioned earlier.

Addition of $0.50 \mathrm{wt} \%$ of MA3 to Al-5Si alloy resulted in complete structural transition from $\alpha$-Al dendritic structure into fine equiaxed $\alpha-\mathrm{Al}$ dendritic structure together with conversion of plate like Si particles into fine fibrous particles (Fig. 10d). This could be due to the presence of newly formed $\mathrm{SrB}_{6}$ along with $\mathrm{Al}_{4} \mathrm{Sr}$ which are responsible for the modification of eutectic $\mathrm{Si}$, whereas, $\mathrm{TiB}_{2}, \mathrm{Al}_{3} \mathrm{Ti}$ and $(\mathrm{Al}, \mathrm{Ti}) \mathrm{B}_{2}$ particles are responsible for grain refinement effect in $\mathrm{Al}-5 \mathrm{Si}$ alloy. The present results of $\mathrm{SEM} / \mathrm{XRD}$ studies are correlated with the results of CA-CCA and DAS analysis. The effect of poisoning is not considered as the phenomena occur (after the addition of grain refiner and grain refiner cum modifier) with increase in holding time ((Bunn et al., 1999; Kori, 2000; Kori et al., 2000a,b). However, in the present work, after the addition of master alloy, the melts of Al-5Si and Al-11Si were poured in to mould after 5 min. of holding time. Hence, no poisoning effect was observed in the present work. 

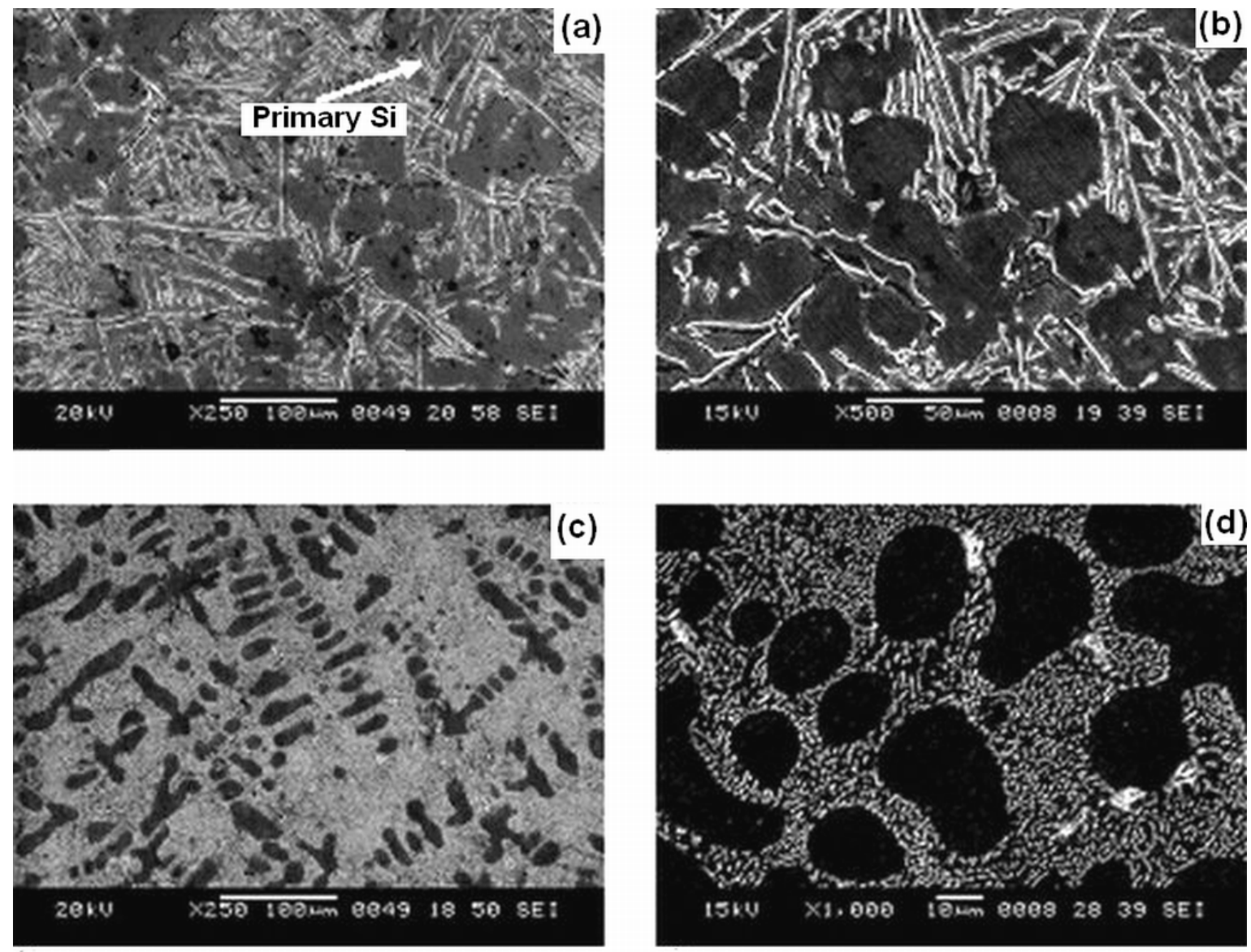

Figure 11 SEM photographs of Al-11Si alloy (a) without master alloy, (b) with 0.65 wt\% of MA1, (c) with 0.30 wt $\%$ of MA2, and (d) with 0.65 wt $\%$ of MA4.

Figure 11a-d shows the SEM photographs of Al-11Si alloy before and after the addition of optimum levels of various master alloys. The microstructure of Al-11Si alloy consists of primarily eutectic mixture $(\alpha-\mathrm{Al}+\mathrm{Si})$ with a considerable amount of elongated $\alpha-\mathrm{Al}$ dendrites and a few star shaped primary Si particles. Normally, the Al-11Si alloy should consist of only eutectic mixture, if it solidifies under equilibrium cooling condition. The presence of $\alpha$-Al as well as seldom found primary silicon particles is due to non equilibrium freezing condition, quick freezing (relative to Al-5Si alloy) and variation in composition. This makes primary Si crystals to nucleate and they grow below the equilibrium liquidus temperature (Gruzleski and Closset, 1990; Kori, 2000; Liao et al., 2007). The liquid around the Si will be enriched in aluminium, as the Si grows. This leads to nucleation of solid aluminium as a block of white light around primary $\mathrm{Si}$ as shown in Fig. 11a. In other words, the presence of $\alpha$-Al as well as the primary silicon is due to the concept of skewed coupled zone. The influence of grain size and its affect on mechanical properties is not studied in detail in this paper. However, the influence of grain refiners and modification of grain size and improvement in some shape memory alloys and effect of strain to alter the grain size is well discussed elsewhere (Silva et al., 2011; Albuquerque et al., 2010d,e). Figure 11a clearly shows that the eutectic mixture is an irregular (divorced eutectic) one, consisting of plate/needle like large Si particles grown in a matrix of $\alpha$-Al. It is clear from the Fig. 11b that the addition of 0.65 wt $\%$ of MA1 to Al-11Si alloy melt results in fine equiaxed $\alpha$-Al dendrites, whereas, Si remains in the unmodified form. Figure 11c shows well-modified structure of more finely dispersed eutectic and primary silicon; however, $\alpha$-Al remains in the columnar form after the addition of $0.30 \mathrm{wt} \%$ of MA2. Figure 11d shows that an optimum addition of 0.65 wt $\%$ of MA4 to Al-11Si alloy results in a complete grain refinement of $\alpha-\mathrm{Al}$ dendrites and modification of eutectic silicon and primary silicon into fine fibrous form. This simultaneous conversion of $\alpha-\mathrm{Al}$, eutectic, and primary $\mathrm{Si}$ is due to the presence of heterogeneous nucleating particles of grain refiner cum modifier which are responsible for simultaneous grain refinement and modification effect. 


\section{Conclusions}

Grain refiner cum modifier is prepared and added to Al-Si alloys. Extent of under cooling is studied and suppression of eutectic temperature is observed. From the work carried out, the following conclusions are drawn.

1. Optimum addition levels of MA1 to Al-5Si and Al-11Si alloys resulted in good grain refinement results. Similarly, MA2 additional levels to Al-5Si and Al-11Si alloys are optimized.

2. Presence of grain refiner (MA1) has no influence on the modification effect of the eutectic Si but presence of modifier (MA2) is responsible for the partial grain refinement of $\alpha$ - $\mathrm{Al}$ dendrites in $\mathrm{Al}-5 \mathrm{Si}$ and $\mathrm{Al}-11 \mathrm{Si}$ alloys.

3. An optimum addition levels of MA3 to Al-5Si alloy and MA4 to Al-11Si alloy showed significant grain refinement and modification, due to the presence of $\mathrm{TiB}_{2},(\mathrm{Al}, \mathrm{Ti}) \mathrm{B}_{2}, \mathrm{Al}_{3} \mathrm{Ti}, \mathrm{Al}_{4} \mathrm{Sr}$ and $\mathrm{SrB}_{6}$ particles.

4. Thermal analysis is considered as an excellent tool to evaluate the efficiency of the grain refiner, modifier, and combined addition. In addition, it can also suggest the grain refining, modification and grain refined cum modified efficiency from the deviation of the original curve (as cast condition).

5. Undercoolings $\left(\Delta \mathrm{T}_{\alpha-\mathrm{Al}}\right)$ were observed in Al-5Si alloy with MA1 and MA2 and with MA2 alloy for Al-11Si alloys. However, zero undercoolings were observed in Al-5Si with MA3 and in Al-11Si alloy with MA1 and MA4, respectively.

\section{Acknowledgements}

The authors are grateful to the Defence Research and Development Organization (DRDO), Ministry of HRD, Government of India, New Delhi for providing financial support to carry out the present work. We are also thankful to Dr. R.N. Herkal, Principal, Basaveshwar Engineering College, Bagalkot for his kind permission to publish this work. We are sincerely thankful to Dr. V.R. Ranganath, Chief Scientist of CSIR-National Aerospace Laboratories, Bangalore for his invaluable help in correcting the manuscript.

\section{References}

Albuquerque V.H.C.; Paulo C. Cortez; Auzuir R. de Alexandria; Joãoo Manuel R. S. Tavares, 2008. A new solution for automatic microstructures analysis from images based on a backpropagation artificial neural network, Nondestructive Testing and Evaluation, Vol. 23, No. 4, pp. 273 - 283

Albuquerque, Victor Hugo Costa de ; Melo, T. A. A. ; Goomes, R. M. ; Lima, S. J. G. ; Tavares, J. M. R. S. .2010a. Grain size and temperature influence on the toughness of a CuAlBe shape memory alloy, Materials Science \& Engineering. A, Structural Materials: Properties, Microstructure and Processing, Vol. 528, p. 459-466, 2010.

Albuquerque, V.H.C.; Melo, T. A. A. ; Goomes, R. M. ; Lima, S. J. G. ; Tavares, J. M. R. S. 2010b. Evaluation of grain refiners influence on the mechanical properties in a CuAlBe shape memory alloy by ultrasonic and mechanical tensile testing, Materials in Engineering (Materials and Design), pp. 3275-3281.

Albuquerque V.H.C, Filho P.P.R., Cavalcante T.S., Tavares J.M.R.S., 2010c. New computational solution to quantify synthetic material porosity from optical microscopic images, Journal of Microscopy, Vol. 240, No. 1, pp. 50-59.

Albuquerque V.H.C, Melo T.A., Gomes R.M., Lima S.J.G., Tavares J.M.R.S., 2010d. Grain Size and Temperature Influence on the Toughness of a CuAlBe Shape Memory Alloy”, Materials Science and Engineering: A Vol. 528, No. 1, pp. :459-466, 2010

Albuquerque V.H.C, Melo T.A., Oliveira D.F., Gomes R.M., Tavares J.M.R.S., 2010e. Evaluation of grain refiners influence on the mechanical properties in a CuAlBe shape memory alloy by ultrasonic and mechanical tension testing, Materials \& Design, Vol. 31, No. 7, pp. 3275-3281, 2010

Albuquerque V.H.C, Cleiton Carvalho Silva, Paulo G. Normando, Elineudo P. Moura, João Manuel R.S. Tavares. 2011. Thermal aging effects on the microstructure of Nb-bearing nickel based superalloy weld overlays using ultrasound techniques. Materials \& Design, In Press.

Apelian D., Sigworth G. K., Whaler K. R., 1984. Assessment of grain refinement and modification of Al-Si foundry alloys by thermal analysis, AFS Transactions, Vol. 92, pp. 297-307.

Bunn A. M., Schumacher P., Kearns M. A., Boothroyd C. B. and Greer A. L., 1999. Grain refinement by Al-Ti-B alloys in aluminium melts: a study of the mechanisms of poisoning by zirconium, Mater Sci. Technol., Vol. 15, pp. 1115-1122.

Basavakumar K. G., Mukunda P. G. and Chakraborty M. 2008. Influence of grain refinement and modification on microstructure and mechanical properties of Al-7Si and Al-7Si-2.5Cu cast alloys, Materials Characterization, Vol. 59, pp. 283-289.

Chen X., Geng H., Li Y., 2006. Study on the eutectic modification level of Al-7Si alloy by computer aided recognition of thermal analysis cooling curves, Materials Science and Engineering A, Vol. 419, pp. 283-289.

Cornish A. J., 1975. The influence of boron on the mechanism of grain refinement in dilute aluminium-titanium alloys, Met. Sci., Vol. 9, pp. 477. 
Dahle A. K., Nogita K., Zindel J. W., McDonald S. D., Hogan L. M., 2001. Eutectic nucleation and growth in hypoeutectic Al-Si alloys at different strontium levels, Metallurgical and Materials Transactions A, Vol. 32A, pp. 949-960.

Dahle A. K., Nogita K., McDonald S. D., Dinnis C., Lu L., 2005. Eutectic modification and microstructure development in Al-Si alloys, Materials Science and Engineering A, Vol. 413-414, pp. 243-248.

Djurdjević M.B., Odanović Z., Pavlović-Krstić J., 2010. Melt quality control at aluminum casting plants, Association of Metallurgical Engineers of Serbia AMES, pp. 63-76.

Fjellstedt J., Jarfors A.E.W. and Svendsen L., 1999. Experimental analysis of the intermediary phases $\mathrm{AlB}_{2}, \mathrm{AlB}_{12}$ and $\mathrm{TiB}_{2}$ in the Al-B and Al-Ti-B system, Journal of Alloys and Compounds, Vol. 283, pp. 192-197.

Gruzleski J.E. and Closset B.M., 1990. The treatment of liquid aluminum-silicon alloys, American Foundrymen's Society, Inc., Des Plaines, Illinois.

Hegde S., Prabhu N., 2008. Modification of eutectic silicon in Al-Si alloys, Journal of Material Science, Vol. 43, pp. 3009-3027.

Hess, P. D., Blackmun, E. V., 1975. Strontium as a modifying agent for hypoeutectic aluminum-silicon alloys, Transactions of the Americal Foundrymen's Society, Vol. 83, pp. 87-90.

Ho C.R., Cantor B., 1995. Modification of hypoeutectic Al-Si alloys, Journal of Materials Science, Vol. 30, No. 8, pp. 1912-1920.

Jones G. P. and Pearson J., 1976. Factors affecting the grain refinement of Al using Ti and B additives, Metallurgical Transactions B., Vol. 7B, pp. 223-234.

Kiusalaas R., 1986. Relation between phases in master alloys of the Al-Ti-B type, Chemical Communications, No. 1, University of Stockholm.

Kori S. A., Rajan T. P. D., Murty B. S., Chakraborty M., 2000b. Assessment of grain refinement and modification of eutectic Al-Si alloys by computer aided cooling curve analysis, Indian Foundry Journal, Vol. 46, No. 8, pp. 35-40.

Kori S. A., 2000. Grain refinement and modification studies of some hypoeutectic and eutectic Al-Si alloys', PhD thesis, IIT Kharagpur.

Kori S. A., Murty B. S. and Chakraborty M., 2000a. Development of an efficient grain refiner for Al-7Si alloy and its modification with strontium, Materials Science and Engineering A, Vol. 283, pp. 94-104.

Liao H., Zhang M., Wu Q., Wang H. and Sun G., 2007. Refinement of eutectic grains by combined addition of strontium and boron in near eutectic Al-Si alloys, Scripta Materialia, Vol. 57, pp. 1121-1124.

Lim Y. P., 2009. Evaluation of Al-5Ti-1B and Al-10Sr in LM-6 sand castings, Journal of Achievements in Materials and Manufacturing Engineering, Vol. 34, No. 1, pp. 71-78.

Lu L. and Dahle A. K., 2006. Effects of combined additions of Sr and AlTiB grain refiners in hypoeutectic Al-Si foundry alloys, Materials Science and Engineering A, Vol. 435-436: pp. 288-296.

Marcantonio J. A. and Mondolfo L. F., 1971. Grain refinement of aluminium alloyed with titanium and boron, Metallurgical Transactions, Vol. 2, pp. 465-471.

Mayes C.D., McCartney D.G. and Tatlock G.J., 1991. Studies on intermetallic phases and grain refining behaviour in Ti/B Master alloys, Light metals 1992, The Minerals, Metals and Materials Society, pp. 813-819.

McCartney D.G., 1989. Grain refining of aluminium and its alloys using inoculants, International Materials Reviews, Vol. 34, pp. 247-260.

Mohanty P.S., Gruzleski J.E., 1996. Grain refinement mechanisms of Hypoeutectic Al-Si alloys, Acta Materialia, Vol. 44, pp. 3749-3760.

Murty B.S., Kori S.A., Venkateswarlu K., Bhat R.R., Chakraborty M., 1999. Manufacture of Al-Ti-B master alloys by the reaction of halide salts with molten aluminium, Journal of Materials Processing Technology, Vol. 89-90, pp. 152-158.

Murty K.S. S., Lakshmi H., 2003. Aluminium Castings, Aluminium Association of India, Bangalore.

Nafisi S., Ghomashchi R., 2007. Boron-based refiners: Implications in conventional casting of Al-Si alloys, Materials Science and Engineering A, Vol. 452-453, pp. 445-453.

Shabestari S. G., Malekan M., 2010. Assessment of the effect of grain refinement on the solidification characteristics of 319 aluminium alloy using thermal analysis, Journal of Alloys and Compounds, Vol. 492, pp. 134-142.

Sigworth G.K., Kuhn T.A., 2007. Grain refinement of aluminium casting alloys, AFS Transactions, Vol. 07-067, No. 2, pp. 1-12.

Uzun O., Yılmaz F., Kolemen U., Basman N., 2011. Sb effect on micro structural and mechanical properties of rapidly solidified Al-12Si alloy, Journal of Alloys and Compounds, Vol. 509, pp. 21-26.

Silva P.M., Abreu H.F.G., Albuquerque V.H.C, Neto P.L., Tavares J.M.R.S., 2011. Cold deformation effect on the microstructures and mechanical properties of AISI 301LN and 316L stainless steels, Materials \& Design Vol. 32, No. 2, pp. 605-614.

\section{Biographical notes}

S. M. Jigajinni is with the Department of Mechanical Engineering, Basaveshwar Engineering College, Bagalkot-587102, INDIA

K. Venkateswarlu is with the CSIR-National Aerospace Laboratories, Bangalore-560017, INDIA 
S. A. Kori is with the Department of Mechanical Engineering, Basaveshwar Engineering College, Bagalkot-587102, INDIA

Received October 2011

Accepted December 2011

Final acceptance in revised form February 2012 